\title{
Microspatial variation in marine biofilm abundance on intertidal rock surfaces
}

\author{
Neil Hutchinson ${ }^{1,3, *}$, Sanjay Nagarkar ${ }^{1}$, Jonathan C. Aitchison ${ }^{2}$, Gray A. Williams ${ }^{1}$ \\ ${ }^{1}$ Swire Institute of Marine Science, Department of Ecology \& Biodiversity, The University of Hong Kong, Pokfulam Road, \\ Hong Kong, SAR \\ ${ }^{2}$ The Department of Earth Sciences, The University of Hong Kong, Pokfulam Road, Hong Kong, SAR \\ ${ }^{3}$ Present address: Amakusa Marine Biological Laboratory, Kyushu University, Tomioka 2231, Reihoku-Amakusa, \\ Kumamoto 863-2507, Japan
}

\begin{abstract}
The effect of substrate surface roughness on small-scale patchiness and the ability of molluscan grazers to feed on intertidal biofilms was examined in a factorial experiment. Granite slabs were treated to create 4 different levels of surface roughness, and biofilm and macroalgae were allowed to recruit. Biofilm cover varied greatly with slab roughness, and was spatially patchy at a scale of millimetres. Diatoms dominated the biofilm, but were less abundant on surfaces with the smallest pits. Cover of diatoms and cyanobacteria was affected by surface roughness, with increased abundance around surface features. Different species of grazer varied in their success at removing certain diatoms and cyanobacteria from slabs of varying roughness, due to either the morphology of the different food types or grazer radula structure. Cover of macroalgal species on the slabs of different roughness also varied, and one species, Hypnea sp., did not recruit on smooth slabs. Rock roughness, therefore, affects both the biofilm and algal species that recruit and their abundance. Grazers were able to remove algae from slabs of all roughness with no apparent species-specific differences in their ability. However, grazer species appear to be more or less efficient at feeding according to the level of roughness, and this combination of variation in rock roughness and grazer efficiency may explain the observed small-scale patchiness on rocky shores in Hong Kong.
\end{abstract}

KEY WORDS: Recruitment $\cdot$ Settlement $\cdot$ Molluscan grazers $\cdot$ Surface roughness $\cdot$ Tropical rocky shore Resale or republication not permitted without written consent of the publishe

\section{INTRODUCTION}

\section{Recruitment on heterogeneous surfaces}

Rocky shore species exhibit spatially variable patterns of settlement and recruitment (Underwood et al. 1983, Hutchinson \& Williams 2001). A variety of physical and biological factors (Hoffmann \& Ugarte 1985) including substrate type and structure (Stephenson 1961, Faimali et al. 2004) have been shown to be partially responsible for causing such patterns. Rock type, for example, influences recruitment patterns for some species of barnacles (e.g. Raimondi 1988) but not for others (Caffey 1982). As such, it appears that organisms are affected by, or react to, surfaces on which they may potentially settle in many different ways (Linskens 1966).
The influence of rock types on the settlement and distribution of biofilms, especially those dominated by cyanobacteria, is well established (Khan 1969, see also review by Wahl 1989). Settlement on bare rock surfaces generally follows a 4 -stage process, which is initiated by bacteria and followed by diatoms, cyanobacteria and finally spores and sporelings of macroalgae (see review by Wahl 1989). The time of initiation of the settlement process can result in temporal variation in these stages (Sousa 1979, Hawkins 1981). In addition, a variety of other factors such as surface chemistry (see review in Railkin 2003), water flow and boundary layer processes (Santos et al. 1991, Percival et al. 1999), physical gap size (Sousa 1984, Dye 1993) and substrate surface roughness (Harlin \& Lindbergh 1977, Walters \& Wethey 1996), are also known to influence settlement processes. Algal 
spores, for example, settled on elevated areas on a rough rock surface when there was no water movement, but in pits on the surface under flowing water conditions (Norton \& Fetter 1981). In this case, settlement was due to the passive physical effect of depressions trapping spores when there was a water current, rather than any active form of selection as demonstrated for some sessile invertebrates (e.g. Crisp \& Barnes 1954). Such patterns may vary depending on the size of the propagules relative to the size of depressions in the rock surface, with an optimum roughness potentially resulting in the greatest settlement and subsequent recruitment (Norton \& Fetter 1981). Information on settlement patterns of the diatoms, cyanobacteria and bacteria that make up epilithic biofilms is, however, far from consistent. In some cases, sparse settlement was recorded on surfaces with increasing roughness (Shreve et al. 1991), whilst in others settlement was enhanced with increasing roughness (Kerr et al. 1999).

\section{Grazing efficiency of herbivorous molluscs}

Molluscan grazers are known to play an important role in rocky shore community structure (reviews by Hawkins \& Hartnoll 1983, Norton et al. 1990). Epilithic grazers on the whole appear to be generalists, consuming the available biofilm, i.e. algae, diatoms, cyanobacteria, invertebrate larvae and, in some cases, the rock substrate itself, often without showing any specific preferences (Hawkins \& Hartnoll 1983 [review], Norton et al. 1990, Hill \& Hawkins 1991). Several grazers exhibit some degree of selection for different components of the biofilm (Nicotri 1980, Hill \& Hawkins 1991). In the case of chemically defended species (see review by Hay \& Fenical 1988), grazers may to a certain degree respond to 'taste', avoiding distasteful species. Generally, however, preferential ingestion of microalgae and other biofilm components is unlikely to be directly selective, but rather an indirect effect of some species (e.g. chain forming diatoms) being easier to capture and ingest than smaller, more tightly adherent species (see discussion in Williams 1992).

Steneck \& Watling (1982) related the variation in diet shown by molluscan grazers to the functional morphology of the grazers, relative to the size and form of their food supply. They argued that grazers with different radula structures would be able to feed on food resources with certain susceptible physical structures (see also Wahl \& Hoppe 2002). Other studies, however, have shown that molluscs with similar radula structures are able to feed on a wide range of food types (Watson \& Norton 1987, Franz 1990), and that radula structure alone does not explain food choice (Raffaelli 1985), but it likely plays an important part in allowing grazers to utilise certain food resources when present (Hawkins et al. 1989).

The impact of this grazing pressure is known to be mediated by spatial variation in physical features on shores, such as crevices or surfaces upon which grazers avoid foraging (such as barnacles; Hawkins \& Hartnoll 1982, Williams et al. 2000). The combination of variation in surface roughness, and the effectiveness and intensity of molluscan grazing is likely to affect the settlement and subsequent recruitment of species to rocky shores. Macroalgal spores and invertebrate larvae, etc. may accumulate in irregularities on the rock surface and, depending on their dimensions these surface irregularities may act as refuges for certain species. The effectiveness of these refuges will be dependent on their size relative to the feeding apparatus of the grazers, and this interaction may drive smallscale spatial variation in biofilms and subsequently shore community structure.

To investigate this potential relationship, variation in the settlement patterns of algae and other species in the epilithic biofilm were monitored on rock surfaces of varying roughnesses. Subsequent recruitment and development under different grazing regimes were tested by allowing molluscan grazers with different radula structures to feed on rocks of different roughness. The experiment was designed to establish the interactive effect of surface roughness and grazing pressure on epilithic species, with the aim of predicting how this may drive small-scale patchiness on rocky shores.

\section{MATERIALS AND METHODS}

Creation of different grades of surface roughness on rock slabs. Commercially available granite slabs $(1 \times 28 \times 28 \mathrm{~cm}$, depth $\times$ length $\times$ width $)$ were used to provide a rock type with physical characteristics similar to the natural granite shores around Hong Kong. Rock slabs were etched in a hydrofluoric acid (HF) bath, which removed silicates and resulted in a roughened rock surface. To create 4 grades of surface roughness, 12 slabs were used for each of 4 treatments: unetched rock slabs with a smooth surface; slabs etched for $24 \mathrm{~h}$ in $5 \% \mathrm{HF}$ to give a slight degree of roughness; slabs etched for $24 \mathrm{~h}$ in $10 \% \mathrm{HF}$ to give a more rough surface, and unetched rock slabs which the supplier had coarsely pre-roughened by flaming $\left(\sum \mathrm{n}=4 \times 12=48\right)$. After etching, the acid was neutralised and both etched and unetched slabs were then scrubbed to remove dirt and the crust of silicates that had built up during the etching process.

The roughness of the 4 rock grades was determined using a modified version of the roughness coefficient 
used by Kostylev (1996). Three tiles of each grade were fractured into $>17$ fragments. The fragments were viewed under a video camera (BXC-107AP; Sony) fitted with a macro lens (Cosmicar television lens, $16 \mathrm{~mm}$ ) at a magnification of $\times 73$, and images of the surface profiles were captured by image analyser (Leica Quantimet 500+). From these images, the length of each side of the individual fragments was measured along the etched surface edge. Fragment surface area was calculated using these measurements and summed to produce a total surface area for each slab (i.e. total surface area $=$ area of Chip $1+2+3 \ldots+n$ ). A roughness coefficient $(r)$ was determined by dividing this 'projected' area by the 'supposed' area of the tile $(28 \times 28 \mathrm{~cm})$; high $r$ values indicate increasing roughness. Mean 'pit' (indentations observed at $\times 73$ magnification on the rock surface) depth and width were also calculated from measurements (using the image analyser) of 100 pits found on the surface of the rock slabs (Table 1). Slabs were categorized as: (1) smooth: original unetched slabs; (2) dotted: original slabs etched in $5 \% \mathrm{HF}_{;}(3)$ mottled: original slabs etched in $10 \% \mathrm{HF}_{\text {; }}$ and (4) pitted: original unetched flameroughened slabs (Table 1 ).

Biofilm growth. Slabs were randomly allocated to 3 sterilised, 1000 l, open air, seawater tanks that had a constant through-flow of seawater and were left for 1 mo (January to February 1999) to allow biofilm growth, which is maximal at this time of year (Nagarkar \& Williams 1999). Within each tank, slabs were situated randomly in order to reduce possible effects of flow direction. This seawater system allowed macroalgal spores, cyanobacteria and diatoms normally found in the water column to pass through the tanks and potentially settle on the surface of the slabs. The tanks were regularly maintained, and after the settlement period slabs were transferred (in moist condition) back to the laboratory, where they were used for grazing experiments. Examination of SEM images of segments suggested that there was no build-up of sediment on any slab.
Grazing efficiency of molluscs. Three common species with different radula structures were selected from the assemblage found on Hong Kong semiexposed rocky shores (Williams 1993, Hutchinson \& Williams 2003). Each species represented 1 of 3 of the categories of radula structure described by Steneck \& Watling (1982), i.e. polyplacophoran (the chiton Acanthopleura japonica; radula width $1400 \mu \mathrm{m}$, marginal teeth $150 \mu \mathrm{m}$, lateral teeth $250 \mu \mathrm{m}$, central teeth $100 \mu \mathrm{m})$, docoglossan (the limpet Cellana toreuma; radula width $275 \mu \mathrm{m}$, marginal teeth $45 \mu \mathrm{m}$, lateral teeth $75 \mu \mathrm{m}$ ) and rhipidoglossan (the top shell Monodonta labio; radula width $1200 \mu \mathrm{m}$, marginal teeth $45 \mu \mathrm{m}$, lateral teeth $100 \mu \mathrm{m}$, central teeth $75 \mu \mathrm{m}$ ) grazers. The dimensions of the radula and individual teeth for each species were estimated by graticule measurements of the radula from 3 individuals of each species under a light microscope.

Once collected, 160 individuals of each species were kept in a clean aquarium with filtered seawater and starved for a period of $3 \mathrm{wk}$. Individuals were chosen that represented the most abundant size classes found on the shore (Acanthopleura japonica $=45$ to $55 \mathrm{~mm}$; Cellana toreuma $=25$ to $30 \mathrm{~mm}$; Monodonta labio $=$ 16 to $20 \mathrm{~mm}$ ). Equal numbers of each species were used in experimental treatments.

All slabs (48 in total) were randomly distributed outside the laboratory in aquaria, where they were sprayed with seawater and surrounded with a mesh fence to prevent grazers escaping. Four treatments were randomly interspersed between the slabs of each grade: no grazers; 10 Acanthopleura japonica; 10 Cellana toreuma and 10 Monodonta labio. Slabs were observed intermittently over $48 \mathrm{~h}$, and the spray adjusted to induce the molluscs to graze for as long a period as possible. After $48 \mathrm{~h}$, the grazers were removed from the slabs.

Visible algae on each of the slabs $(\Sigma \mathrm{n}=4$ roughness grades $\times 4$ grazers treatments [ 3 with grazers and 1 grazer-free control] $\times 3$ replicates $=48$ ) were scored using a $25 \times 25 \mathrm{~cm}, 100$ point, double strung quadrat

Table 1. Summary of mean $( \pm \mathrm{SD})$ slab $(\mathrm{n}=3)$ and pit $(\mathrm{n}=100)$ dimensions for granite rock slab treatments. Higher roughness coefficient values represent surfaces of high roughness. Pitted slabs had pits at 2 spatial scales, i.e. the inner surface of large pits was broken up by small pits, hence, 2 values for pit dimensions. 'Assumed' grade represents a slab with no surface irregularities

\begin{tabular}{|c|c|c|c|c|c|}
\hline $\begin{array}{l}\text { Slab } \\
\text { grade }\end{array}$ & Treatment & $\begin{array}{c}\text { 'Projected' area } \\
\left(\mathrm{cm}^{2}\right)\end{array}$ & $\begin{array}{c}\text { Roughness } \\
(r)\end{array}$ & $\begin{array}{l}\text { Pit width } \\
\qquad(\mu \mathrm{m})\end{array}$ & $\begin{array}{l}\text { Pit depth } \\
\quad(\mu \mathrm{m})\end{array}$ \\
\hline Dotted & Etched in $5 \% \mathrm{HF}$ & $1580 \pm 73$ & 2.02 & $240 \pm 90$ & $120 \pm 40$ \\
\hline Mottled & Etched in $10 \% \mathrm{HF}$ & $1779 \pm 53$ & 2.27 & $260 \pm 70$ & $180 \pm 70$ \\
\hline Pitted & Flamed slabs & $2106 \pm 111$ & 2.69 & $\begin{array}{c}14500 \pm 380 \\
230 \pm 80\end{array}$ & $\begin{array}{r}2350 \pm 78 \\
110 \pm 70\end{array}$ \\
\hline Smooth & Unetched & $862 \pm 87$ & 1.10 & $160 \pm 60$ & $80 \pm 30$ \\
\hline Assumed & - & 784 & 1 & - & - \\
\hline
\end{tabular}


placed in the centre of each slab prior to and following grazer addition. After $48 \mathrm{~h}$, the slabs were fractured into small fragments $\left(\sim 4 \mathrm{~cm}^{2}\right), 3$ from each slab were selected haphazardly from areas where molluscs had been observed grazing, and chlorophyll a concentration was estimated using the cold methanol method (Nagarkar \& Williams 1997). Three extra fragments were haphazardly selected and prepared for observation under the scanning electron microscope (SEM; Leica Cambridge S440), after preservation in $2.5 \%$ glutaraldehyde for $2 \mathrm{~h}$, and rinsing with distilled water and air drying for $12 \mathrm{~h}$ before coating with gold/palladium (Nagarkar \& Williams 1997). The percentage cover of biofilm species was recorded from 5 haphazard fields of view photographed at $\times 500$ under the SEM and scored with a 100-point overlay (Nagarkar \& Williams 1997). These fragments were also qualitatively examined to determine whether surface irregularities, such as pits, led to any patterns in the distribution of algal cells over the rock surface, and whether it was possible to observe damage of the biofilm caused by grazing.

Spatial variation in macroalgae was determined separately for slabs before and after grazing using 2 -factor analysis of variance (ANOVA) with grazer treatment ( $\operatorname{Tr}$ ) (4 levels, fixed) and slab roughness (Ro) (4 levels, fixed). In all analyses, data were tested for homogeneity of variance using Cochran's $C$-test, transformed where necessary, and significant differences were further examined using Student-Newman-Keuls (SNK) tests where applicable. Differences in chlorophyll a concentration were examined using 2 -factor

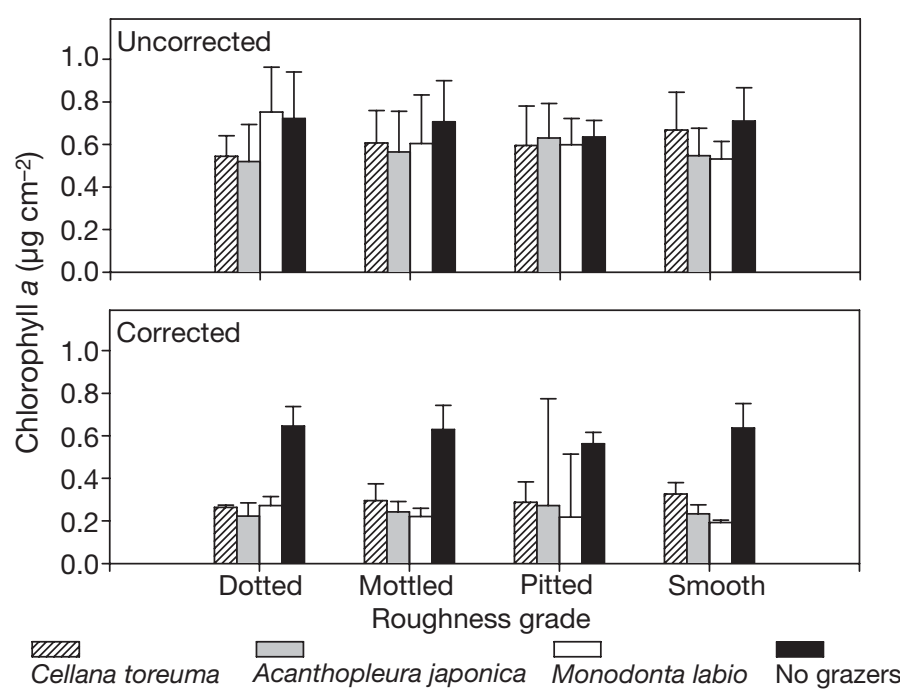

Fig. 1. Variation in mean $(+\mathrm{SD}, \mathrm{n}=3$ ) chlorophyll a concentration on rock slabs under different grazing treatments. Graphs show both uncorrected and corrected data for surface roughness and 'projected' surface roughness, respectively (see 'Materials and methods'). Treatments as in Table 1
ANOVA on mean values ( $\mathrm{n}=3$ fragments) of chlorophyll a obtained for each slab, with grazer treatment (4 levels) and roughness (4 levels). Analysis was also conducted on values that were corrected for surface area using the 'projected' surface area estimates calculated in the determination of $r$.

To determine variation in biofilm cover, 2 -factor ANOVA was performed using mean cover data $(\mathrm{n}=3)$ for each rock slab. Diatom species were grouped for analysis of total diatoms, and the most abundant cyanobacteria species were placed into 2 groups: Lyngbya spp./Oscillatoria spp. and unicellular cyanobacteria. Differences were determined between grazer treatment (4 levels) and roughness (4 levels). Species viewed under the SEM were grouped into 3 size classes: 1-20 $\mu \mathrm{m}, \quad 30-60 \mu \mathrm{m}$ and $0.5-3 \mathrm{~mm}$ (see Table 2), and separate analyses were performed using the same model to determine whether there was any variation in the distribution of different sizes of biofilm species on slabs of different roughness.

\section{RESULTS}

\section{Variation in cover of biofilm species}

Chlorophyll a concentration on rock slabs was generally highest on smooth slabs (Fig. 1), although initial analysis found no significant difference between roughness grades or grazer treatments (see Table 3). When values were corrected for the 'projected' area of the surface (i.e. accounting for surface roughness), higher chlorophyll a concentrations were recorded on slabs where no grazers had been introduced (MS = $0.4225, F=91.93, \mathrm{p}<0.0001$ ), but no differences between grazer species was found.

Biofilm species on rock slabs consisted of diatoms and cyanobacteria, with 27 species in total (Table 2). The most abundant micro-organisms were diatoms (15 species; Fig. 2, Table 2), consisting mainly of Achnanthes spp., Licmophora sp. and Amphora sp., as well as rare occurrences of 14 other species (not discussed further). In contrast to the diatoms, the percentage cover of cyanobacteria was sparse (although there were a high number of species, 15 in all), consisting mainly of filamentous Lyngbya spp. and Oscillatoria spp. with isolated Phormidium spp. and Calothrix spp.

Biofilm cover varied widely and was patchy at a scale of millimetres on rock fragments viewed under the SEM (see high SD levels in Fig. 2). Total cover varied widely between slabs, with significant interactions between surface roughness and grazer treatment (Table 3). There was a higher cover on all roughness grades that had not been grazed (Fig. 2, Table 3) and on the pitted slabs (i.e. the roughest grade), where 
Table 2. Summary of sessile species growing on experimental slabs of all roughnesses in the present study, and allocated size groups (identification after Round et al. 1990 and Nagarkar 1998). The size group for Achnanthes spp. $=30$ to $60 \mu \mathrm{m}$

\begin{tabular}{|c|c|c|}
\hline Species & Shape & Width $(\mu \mathrm{m})$ \\
\hline \multicolumn{3}{|c|}{ Macroalgae (0.5 to $3 \mathrm{~mm}$ size group) } \\
\hline Enteromorpha sp. & Filament & 1000 \\
\hline Ulva sp. & Erect blades & $1000-2000$ \\
\hline Porphyra suborbiculata & Erect blades & $2000-3000$ \\
\hline Hypnea sp. & Branched filament & 500 \\
\hline \multicolumn{3}{|l|}{ Diatoms (1 to $20 \mu \mathrm{m}$ size group) } \\
\hline Achnanthes spp. (2 spp. $)^{\mathrm{a}}$ & Heterovalvar & $30-60$ \\
\hline Licmophora sp. ${ }^{\mathrm{a}}$ & Fan-shaped & 20 \\
\hline Amphora sp. ${ }^{\mathrm{a}}$ & Cymbeloid & 10 \\
\hline Navicula spp. (6 spp.) & Naviculoid & 20 \\
\hline Fragilaria sp. & Ribbon-like & 10 \\
\hline Melosira sp. & Subspherical & 15 \\
\hline Cocconeis spp. (2 spp.) & Heterovalvar & 10 \\
\hline Skeletonema sp. & Filament & 10 \\
\hline \multicolumn{3}{|c|}{ Cyanobacteria (1 to $20 \mu \mathrm{m}$ size group) } \\
\hline \multicolumn{3}{|l|}{ Colonial } \\
\hline Phormidium tenue & Filament & $1-3$ \\
\hline Phormidium corium & Filament & $1-3$ \\
\hline Lyngbya martensiana $^{a}$ & Filament & $5-15$ \\
\hline Lyngbya semiplena ${ }^{a}$ & Filament & $6-7$ \\
\hline Lyngbya confervoides $^{\text {a }}$ & Filament & $12-14$ \\
\hline Spirulina subsalsa & Trichome & $1.5-2.5$ \\
\hline Oscillatoria subbrevis ${ }^{\mathrm{a}}$ & Trichome & $7-9$ \\
\hline Oscillatotia vizagapatensis ${ }^{\mathrm{a}}$ & Trichome & $7-9$ \\
\hline Calothrix scopulorum & Tapering filament & $9-17 / 4-7$ \\
\hline Calothrix contarenii & Tapering filament & $9-17 / 4-7$ \\
\hline Calothrix crustacea & Tapering filament & $9-17 / 4-7$ \\
\hline \multicolumn{3}{|l|}{ Unicellular } \\
\hline Aphanocapsa sesciansis & Spherical & $4-12$ \\
\hline Chroococcus crepidinum & Spherical & $4-6$ \\
\hline Dermocarpa olivacea & Spherical & $15-20$ \\
\hline Gloecapsa crepidinum & Spherical & $4-10$ \\
\hline
\end{tabular}

grade), where those grazed by $M$. labio had significantly less cover than the other grazer treatments.

Macroalgae viewed under the SEM varied significantly between treatments with higher coverage on slabs which had not been grazed. This pattern was also seen for unicellular cyanobacteria species, although significant differences between roughness grades were also seen for this group but could not be further isolated by SNK tests (Table 3). There was considerable variation in occurrence of the Lyngbya spp./Oscillatoria spp. group, with significantly higher cover on smooth or mottled slabs with no grazers or those grazed by Acanthopleura japonica (Table 3). Percentage cover on 'smooth' slabs grazed by A. japonica was significantly higher than in other treatments (Table 3).

\section{Variation in size of biofilm constituents}

The cover of the 3 pre-determined size classes (Table 2) varied with both grazer treatment and surface roughness (Fig. 3, Table 4). The smallest group (1 to $20 \mu \mathrm{m}$ ) had significantly greater cover on pitted slabs (the roughest grade) than on smooth slabs, which in turn had greater cover than mottled and dotted slabs (Table 4). Overall, the general pattern was of higher cover of all groups on the more rough and ungrazed slabs.

For the 30 to $60 \mu \mathrm{m}$ size class there was a significant interaction between grazer treatment and surface roughness, with the greatest cover on ungrazed slabs, usually followed by slabs

percentage cover was significantly less on slabs grazed by Monodonta labio than on slabs grazed by other species (Fig. 2, Table 3). Total cover also varied significantly between roughness grades for both Cellana toreuma and Acanthopleura japonica (Table 3), with higher cover on pitted and mottled slabs (high roughness grades) for $C$. toreuma and on pitted slabs for A. japonica, than on the lower roughness grades.

Diatom cover varied significantly between slabs with interactions between roughness grade and grazer treatment (Fig. 2, Table 3). While there was a consistently higher cover on slabs which had not been grazed, this was only significant on smooth slabs. The next highest coverage was found on slabs grazed by Acanthopleura japonica, followed by Cellana toreuma and Monodonta labio, although there were exceptions for smooth slabs, where those grazed by $C$. toreuma had the lowest cover and for pitted slabs (the roughest grazed by Acanthopleura japonica and then either Cellana toreuma or Monodonta labio (Table 4). Slabs with a dotted surface proved an exception, with the most sparse cover of species in the 30 to $60 \mu \mathrm{m}$ size class being found on slabs that were ungrazed or grazed by $A$. japonica. Cover on ungrazed slabs of the 4 roughness grades varied between treatments, being highest on smooth slabs, followed by higher cover on pitted than on mottled slabs, and on mottled than on dotted slabs. For slabs grazed by M. labio, the highest cover occurred on mottled slabs, followed by higher cover on dotted than on pitted slabs (the roughest grade), and on pitted than on smooth slabs (Table 4).

For the largest size class $(0.5$ to $3 \mathrm{~mm})$ there was no significant variation in percentage cover on slabs of different roughness grades, but cover was significantly greater on slabs which were not grazed than on slabs in other treatments (Table 4). 


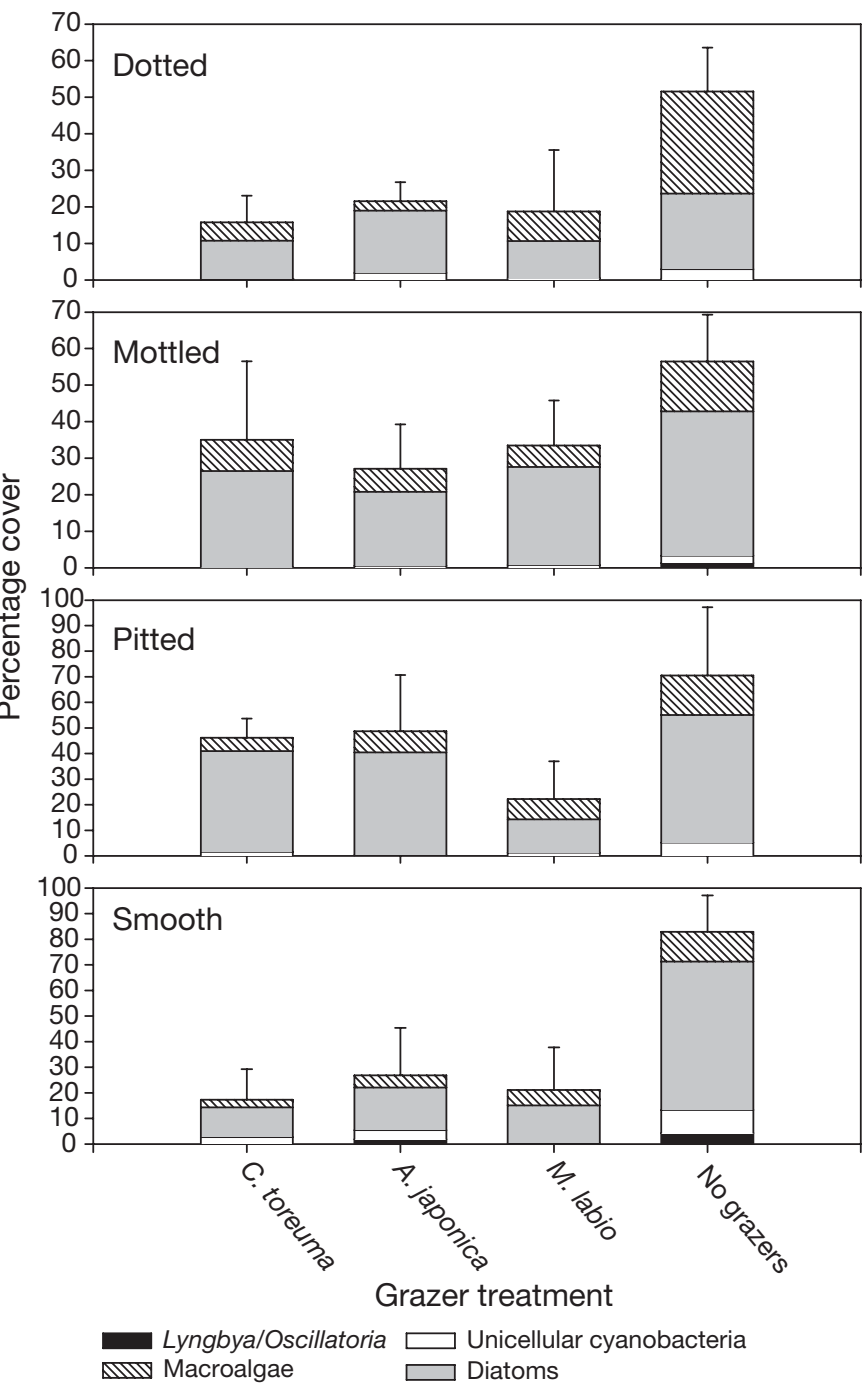

Fig. 2. Variation in mean $(+\mathrm{SD}, \mathrm{n}=3)$ percentage cover of micro-organism groups on rock slabs under different grazing treatments $(+\mathrm{SD}, \mathrm{n}=3)$. Note scale change. Full grazer species names as in Fig. 1

\section{Variation in cover of macroalgal species}

After 1 mo in the seawater tanks slabs were covered with a sparse ( 5 to $30 \%)$ macroalgal turf consisting of the erect species Enteromorpha sp., Porphyra suborbiculata, Ulva sp. and Hypnea sp. While there was no significant difference in total cover on slabs of different roughness (Table 5), cover of individual species did vary significantly (Fig. 4, Table 5). Enteromorpha sp. sporelings (1000 $\mathrm{mm}$ width) covered a larger percentage of rock surface on dotted and pitted roughness grades than on mottled and smooth grades (see Table 1 for dimensions), whereas the opposite pattern was seen for $P$. suborbiculata (Table 5). There was a significantly greater coverage of Ulva sp. on smooth slabs

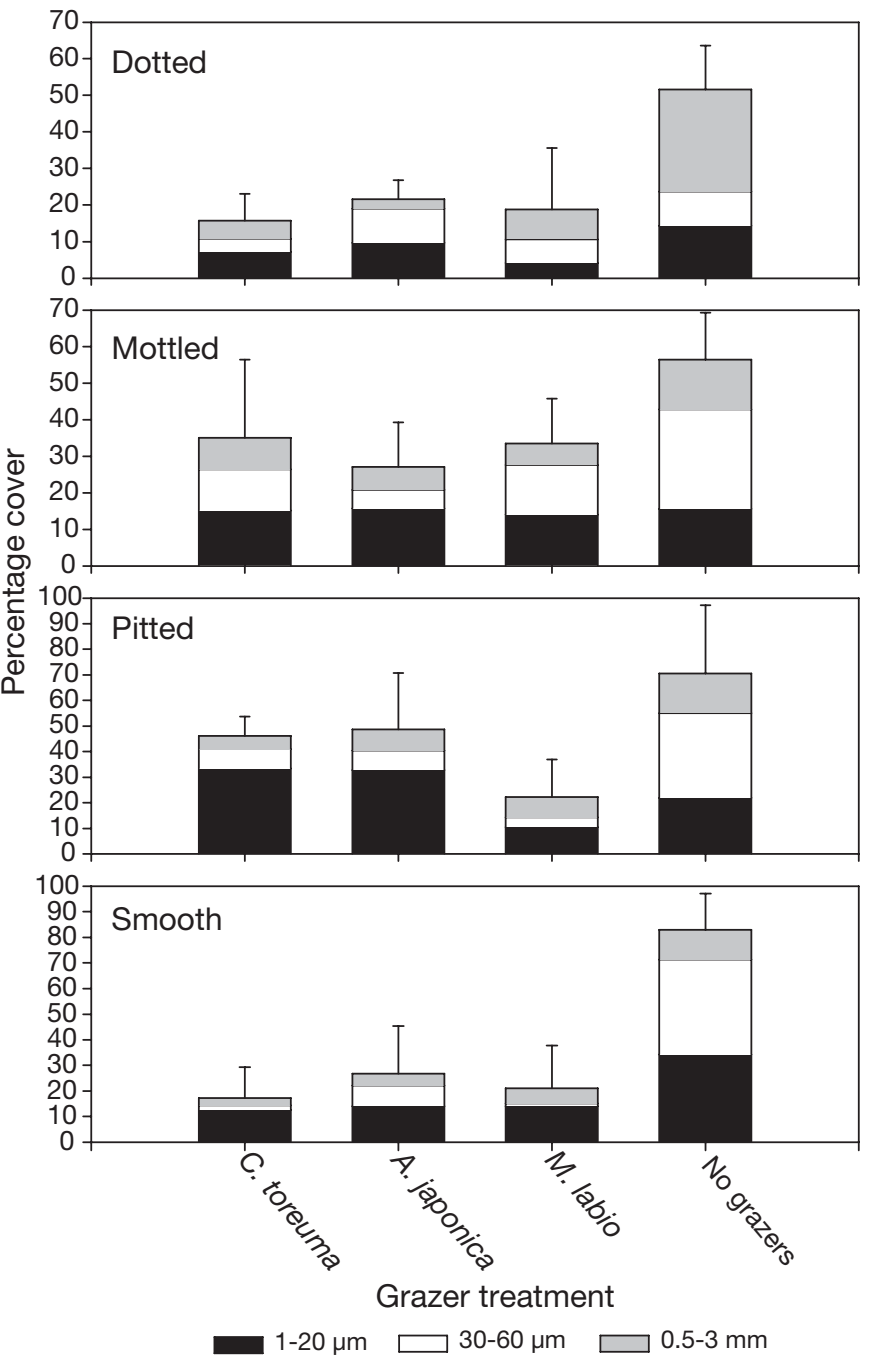

Fig. 3. Variation in mean $(+\mathrm{SD}, \mathrm{n}=3)$ percentage cover of size groups of epilithic species on rock slabs under different grazing treatments $(+\mathrm{SD}, \mathrm{n}=3)$. Note scale change. Full grazer species names as in Fig. 1

than on the other roughness grades in contrast to cover of Hypnea sp., which was greater on the dotted and mottled slabs than on the pitted grade, and did not occur at all on smooth slabs (Fig. 4). There were, however, no significant differences between slabs prior to the introduction of the different grazer treatments (Table 5). After $48 \mathrm{~h}$ of the 4 different grazer treatments, there was a decrease in the total cover of macroalgae on slabs of all roughness grades (Fig. 4). Overall patterns of variation in the percentage cover of both total algae and individual species on the different roughness grades did not, however, change following grazing (Tables 5 \& 6).

There was significant variation in the cover of algae between grazer treatments after $48 \mathrm{~h}$ (Fig. 4, Table 6). A 
Table 3. Comparison using 2-factor ANOVA of variation in percentage cover of micro-organisms (after $48 \mathrm{~h}$ grazing treatment) between slabs with different rock roughnesses (Ro) and grazer treatment (Tr). Data for unicellular cyanobacteria and Lyngbya spp./Oscillatoria spp. were $\ln (x+1)$ - and $x^{0.0015}$-transformed respectively. Significant differences are shown in bold and were examined further using SNK tests. D: dotted; M: mottled; P: pitted; S: smooth; Aj: Acanthopleura japonica; Ct: Cellana toreuma; Ml: Monodonta labio; N: no grazers

\begin{tabular}{|c|c|c|c|c|c|c|}
\hline Source & df & MS & $F$ & $\mathrm{p}$ & $-\mathrm{s}$ & NK \\
\hline \multicolumn{5}{|c|}{ Total species } & Grazer & Roughness \\
\hline Ro & 3 & 803.3353 & 7.49 & 0.0006 & Ct: $\mathrm{P}=\mathrm{M}>\mathrm{S}=\mathrm{D}$ & $\mathrm{D}: \mathrm{N}>\mathrm{Aj}=\mathrm{Ml}=\mathrm{Ct}$ \\
\hline $\operatorname{Tr}$ & 3 & 4338.9558 & 40.47 & $<0.0001$ & Aj: $P>M=S=D$ & $\mathrm{M}: \mathrm{N}>\mathrm{Ct}=\mathrm{Ml}=\mathrm{Aj}$ \\
\hline $\operatorname{Ro} \times \operatorname{Tr}$ & 9 & 337.5077 & 3.15 & 0.0079 & Ml: $\mathrm{M}=\mathrm{P}=\mathrm{S}=\mathrm{D}$ & $\mathrm{P}: \mathrm{N}>\mathrm{Aj}=\mathrm{Ct}>\mathrm{Ml}$ \\
\hline Residual & 32 & 107.2071 & & & $\mathrm{~N}: \mathrm{S}=\mathrm{P}=\mathrm{M}=\mathrm{D}$ & $\mathrm{S}: \mathrm{N}>\mathrm{Aj}=\mathrm{Ml}=\mathrm{Ct}$ \\
\hline \multicolumn{5}{|l|}{ Diatoms } & Grazer & Roughness \\
\hline Ro & 3 & 913.6159 & 11.25 & $<0.0001$ & $\mathrm{Ct}: \mathrm{P}=\mathrm{D}=\mathrm{M}=\mathrm{S}$ & $\mathrm{D}: \mathrm{N}=\mathrm{Aj}=\mathrm{Ct}=\mathrm{Ml}$ \\
\hline $\operatorname{Tr}$ & 3 & 1500.1169 & 18.48 & $<0.0001$ & $\mathrm{Aj}: \mathrm{P}>\mathrm{M}=\mathrm{D}=\mathrm{S}$ & $\mathrm{M}: \mathrm{N}=\mathrm{Aj}=\mathrm{Ct}=\mathrm{Ml}$ \\
\hline $\operatorname{Ro} \times \operatorname{Tr}$ & 9 & 322.4116 & 3.97 & 0.0018 & Ml: $\mathrm{M}=\mathrm{S}=\mathrm{P}=\mathrm{D}$ & $P: N=A j=C t>M l$ \\
\hline Residual & 32 & 81.1748 & & & $\mathrm{~N}: \mathrm{S}=\mathrm{P}=\mathrm{M}>\mathrm{D}$ & $\mathrm{S}: \mathrm{N}>\mathrm{Aj}=\mathrm{Ml}=\mathrm{Ct}$ \\
\hline \multicolumn{7}{|l|}{ Macroalgae } \\
\hline Ro & 3 & 43.5394 & 1.24 & 0.3128 & & \\
\hline $\operatorname{Tr}$ & 3 & 384.5604 & 10.92 & $<0.0001$ & $\mathrm{~N}>\mathrm{Ml}=\mathrm{Aj}=\mathrm{Ct}$ & \\
\hline $\operatorname{Ro} \times \operatorname{Tr}$ & 9 & 52.0565 & 1.48 & 0.1984 & & \\
\hline Residual & 32 & 35.2440 & & & & \\
\hline \multicolumn{7}{|c|}{ Unicellular cyanobacteria } \\
\hline Ro & 3 & 1.2879 & 3.00 & 0.0450 & $\mathrm{~S}=\mathrm{P}=\mathrm{D}=\mathrm{M}$ & \\
\hline $\operatorname{Tr}$ & 3 & 2.6203 & 6.10 & 0.0021 & $\mathrm{~N}>\mathrm{Aj}=\mathrm{Ct}=\mathrm{Ml}$ & \\
\hline $\operatorname{Ro} \times \operatorname{Tr}$ & 9 & 0.4845 & 1.13 & 0.3722 & & \\
\hline Residual & 32 & 0.4294 & & & & \\
\hline \multicolumn{5}{|c|}{ Lyngbya spp./Oscillatoria spp. } & Grazer & Roughness \\
\hline Ro & 3 & 0.5010 & 8.00 & 0.0004 & $\mathrm{Ct}: \mathrm{M}=\mathrm{S}=\mathrm{P}=\mathrm{D}$ & $\mathrm{D}: \mathrm{N}=\mathrm{Ml}=\mathrm{Aj}=\mathrm{Ct}$ \\
\hline $\operatorname{Tr}$ & 3 & 0.2785 & 4.45 & 0.0101 & Aj: $S>P=M=D$ & $\mathrm{M}: \mathrm{N}=\mathrm{Ct}=\mathrm{Ml}=\mathrm{Aj}$ \\
\hline $\operatorname{Ro} \times \operatorname{Tr}$ & 9 & 0.2595 & 4.14 & 0.0013 & $\mathrm{Ml}: \mathrm{S}=\mathrm{P}=\mathrm{M}=\mathrm{D}$ & $P: N=M l=A j=C t$ \\
\hline Residual & 32 & 0.0626 & & & $\mathrm{~N}: \mathrm{S}=\mathrm{M}>\mathrm{P}=\mathrm{D}$ & $\mathrm{S}: \mathrm{Aj}=\mathrm{N}>\mathrm{Ml}=\mathrm{Ct}$ \\
\hline
\end{tabular}

caution should be employed when inferring natural patterns from such laboratory-based work. Despite this shortcoming, settlement processes resembled those which occur on Hong Kong shores (Williams et al. 2000). In the present study, a common settlement pattern of diatoms followed by cyanobacteria and finally spores and sporelings of macroalgae was recorded (MacLulich 1986). Surface roughness is known to effect patterns of biofilm distribution (e.g. Kerr et al. 1999), but becomes less important as depressions and pits fill with detritus and secondary succession begins. This is in agreement with the observations in the present study, where no significant variation in total biofilm cover was recorded on ungrazed slabs of different roughness. Conversley, diatom cover did vary, with lower cover on surfaces with small, shallow pits than on all other surfaces. Such patterns are probably due to the size of pits, as diatoms occurred in greater abundances on the open surfaces of these slabs. Finer- higher total algal cover was found on ungrazed slabs (Fig. 4, Table 6) and a similar pattern was seen for Porphyra suborbiculata (Fig. 4, Table 6). The cover of Ulva sp. (Fig. 4) also varied with grazer treatment, but further isolation of differences was not possible using SNK tests (Table 6). Both Enteromorpha sp. and Hypnea sp. showed no significant effect of grazers, although Нypnea sp. showed a slight decrease on slabs grazed by Acanthopleura japonica (Fig. 4). The effect of grazers on macroalgal cover did not interact with surface roughness for any of the grazer species (Table 6), i.e. grazers did not decrease percentage cover of an algae species more on one roughness grade than on another.

\section{DISCUSSION}

Intertidal systems, in contrast to the present experimental conditions, are affected by various physical factors such as water movement due to wave splash, tidal flow and water current. As the present study was seeded in seawater tanks, these factors were limited and species occurring on experimental slabs were not necessarily abundant on the shore (e.g. Hypnea spp. and cyanobacteria; S. Nagarkar pers. obs.); as a result,
Table 4. Comparison using 2-factor ANOVA of variation in percentage cover of 3 size classes of micro-organisms (1-20 $\mu \mathrm{m}, 30-60 \mu \mathrm{m}$ and $0.5-3 \mathrm{~mm}$; see Table 2) between slabs with different rock roughnesses (Ro) and grazer treatment (Tr). Significant differences are shown in bold and were examined further using SNK tests. Abbreviations as in Table 3

\begin{tabular}{|c|c|c|c|c|c|}
\hline Source & df & MS & $F$ & $\mathrm{p}$ & SNK \\
\hline \multicolumn{6}{|c|}{$1-20 \mu \mathrm{m}$ size class } \\
\hline Ro & 3 & 524.08 & 6.12 & 0.002 & \multirow[t]{4}{*}{$\mathrm{P}>\mathrm{S}>\mathrm{M}>\mathrm{D}$} \\
\hline $\operatorname{Tr}$ & 3 & 246.44 & 2.88 & 0.051 & \\
\hline $\operatorname{Ro} \times \operatorname{Tr}$ & 9 & 161.80 & 1.89 & 0.090 & \\
\hline Residual & 32 & 85.7 & & & \\
\hline \multicolumn{6}{|c|}{$30-60 \mu \mathrm{m}$ size class } \\
\hline Ro & 3 & 116.49 & 2.52 & 0.075 & \multirow{4}{*}{ See below } \\
\hline $\operatorname{Tr}$ & 3 & 1217.92 & 26.37 & $<0.0001$ & \\
\hline $\operatorname{Ro} \times \operatorname{Tr}$ & 9 & 161.08 & 3.49 & 0.004 & \\
\hline Residual & 32 & 46.19 & & & \\
\hline \multirow[t]{5}{*}{ SNK tests } & \multirow{5}{*}{\multicolumn{5}{|c|}{$\begin{array}{c}\text { Roughness } \\
\text { D: } \mathrm{N}=\mathrm{Aj}>\mathrm{Ml}>\mathrm{Ct} \\
\mathrm{M}: \mathrm{N}>\mathrm{Ml}>\mathrm{Ct}>\mathrm{Aj} \\
\mathrm{P}: \mathrm{N}>\mathrm{Aj}=\mathrm{Ct}>\mathrm{MI} \\
\mathrm{S}: \mathrm{N}>\mathrm{Aj}>\mathrm{Ct}=\mathrm{Ml}\end{array}$}} \\
\hline & & & & & \\
\hline & & & & & \\
\hline & & & & & \\
\hline & & & & & \\
\hline \multicolumn{6}{|c|}{$0.5-3 \mathrm{~mm}$ size class } \\
\hline Ro & 3 & 43.54 & 1.24 & 0.313 & \multirow{4}{*}{$\mathrm{N}>\mathrm{Ml}=\mathrm{Aj}=\mathrm{Ct}$} \\
\hline $\operatorname{Tr}$ & 3 & 384.56 & 10.92 & $<0.0001$ & \\
\hline $\operatorname{Ro} \times \operatorname{Tr}$ & 9 & 52.06 & 1.48 & 0.198 & \\
\hline Residual & 32 & 35.22 & & & \\
\hline
\end{tabular}


Table 5. Comparison using 2-factor ANOVA of variation in percentage cover of macroalgae prior to addition of grazers between slabs with different rock roughnesses (Ro) and potential grazer treatment (Tr). Data for Hypnea sp. were square $\operatorname{root}(x+1)$-transformed to homogenise variances. Significant differences are shown in bold and were examined further using SNK tests. Abbreviations as in Table 3

\begin{tabular}{|c|c|c|c|c|c|}
\hline Source & $\mathrm{df}$ & MS & $F$ & $\mathrm{p}$ & SNK \\
\hline \multicolumn{6}{|l|}{ Total cover } \\
\hline Ro & 3 & 315.2778 & 2.73 & 0.0598 & \\
\hline $\operatorname{Tr}$ & 3 & 39.2222 & 0.34 & 0.7964 & \\
\hline $\operatorname{Ro} \times \operatorname{Tr}$ & 9 & 68.4259 & 0.59 & 0.7926 & \\
\hline Residual & 32 & 115.2917 & & & \\
\hline \multicolumn{6}{|c|}{ Enteromorpha sp. } \\
\hline Ro & 3 & 416.7986 & 19.81 & $<0.0001$ & $\mathrm{D}=\mathrm{P}>\mathrm{S}=\mathrm{M}$ \\
\hline $\operatorname{Tr}$ & 3 & 43.7431 & 2.08 & 0.1226 & \\
\hline $\operatorname{Ro} \times \operatorname{Tr}$ & 9 & 26.2616 & 1.25 & 3.022 & \\
\hline Residual & 32 & 21.0417 & & & \\
\hline \multicolumn{6}{|c|}{ Porphyra suborbiculata } \\
\hline Ro & 3 & 401.1875 & 15.17 & $<0.0001$ & $\mathrm{~S}=\mathrm{M}>\mathrm{P}=\mathrm{D}$ \\
\hline $\operatorname{Tr}$ & 3 & 7.9097 & 0.30 & 0.8257 & \\
\hline $\operatorname{Ro} \times \operatorname{Tr}$ & 9 & 21.7431 & 0.82 & 0.6002 & \\
\hline Residual & 32 & 26.4375 & & & \\
\hline \multicolumn{6}{|l|}{ Ulva sp. } \\
\hline Ro & 3 & 430.7222 & 15.70 & $<0.0001$ & $\mathrm{~S}>\mathrm{M}=\mathrm{D}=\mathrm{P}$ \\
\hline $\operatorname{Tr}$ & 3 & 7.3889 & 0.27 & 0.8470 & \\
\hline $\operatorname{Ro} \times \operatorname{Tr}$ & 9 & 10.7037 & 0.39 & 0.9310 & \\
\hline Residual & 32 & 27.4375 & & & \\
\hline \multicolumn{6}{|l|}{ Hypnea sp. } \\
\hline Ro & 3 & 9.1961 & 25.42 & $<0.0001$ & $\mathrm{M}=\mathrm{D}>\mathrm{P}=\mathrm{S}$ \\
\hline $\operatorname{Tr}$ & 3 & 0.2881 & 0.80 & 0.5051 & \\
\hline $\operatorname{Ro} \times \operatorname{Tr}$ & 9 & 0.2935 & 0.81 & 0.6097 & \\
\hline Residual & 32 & 0.3618 & & & \\
\hline
\end{tabular}

scale surface features were not, as expected, filled with diatoms (possibly due to relatively low light penetration) and, in some cases, diatom abundance appeared higher around raised features.

Cyanobacteria cover varied with surface roughness in relation to cell size and settlement patterns. Abundance of filamentous species, including species of Lyngbya and Oscillatoria, was highest on smooth grades and grades with the largest pits, i.e. pitted slabs. The cover of cyanobacteria was extremely low compared to that on the shore (Nagarkar \& Williams 1999, Williams et al. 2000), possibly due to coarse filtration of the water prior to its introduction into the tanks.

Cover of macroalgae varied depending on slab roughness, with Ulva sp. occurring in greater abundance on smooth surfaces and other species varying on surfaces of different roughness. Variable distribution patterns for algae on surfaces of different roughness are known to occur on natural shores (Underwood \& Jernakoff 1981) and in freshwater systems (Sanson et al. 1995), and have been attributed to passive settlement patterns of propagules that may accumulate in depressions on the rock surface (e.g. Norton \& Fetter
1981). On rocky shores, small-scale (metres to centimetres) spatial patterns of algal distribution may, therefore, be influenced by variation in substratum roughness.

Surprisingly (in view of the degree of variation in the distribution of algal and cyanobacterial species), there was negligible variation in chlorophyll a concentration with slab roughness. Correcting for surface area differences, however, revealed that concentrations were higher on ungrazed treatments. As suggested by Thompson et al. (1999), the present method of measuring chlorophyll a may be inaccurate if samples are taken from surfaces with great, small-scale, differences in roughness, and a more accurate measure of surface area is desirable. Using image analysis to produce projected values for surface area is time consuming and still an approximation of true roughness, and a more reliable and accurate method to ascertain surface area would help to refine estimates of chlorophyll a concentrations.

Actively foraging grazers affected macroalgal cover, reducing abundance on slabs of all roughnesses. Cover of Ulva sp. decreased in the presence of grazers, with the greatest removal occurring on smooth slabs grazed

Table 6. Comparison using 2-factor ANOVA of variation in percentage cover of macroalgae, after $48 \mathrm{~h}$ grazing, between slabs with different rock roughnesses (Ro) and grazer treatment (Tr). Significant differences are shown in bold and were examined further using SNK tests. Abbreviations as in Table 3

\begin{tabular}{|c|c|c|c|c|c|}
\hline Source & df & MS & $F$ & $\mathrm{p}$ & SNK \\
\hline \multicolumn{6}{|l|}{ Total algae } \\
\hline Ro & 3 & 167.8056 & 1.88 & 0.1535 & \\
\hline $\operatorname{Tr}$ & 3 & 588.0278 & 6.57 & 0.0014 & $\mathrm{~N}>\mathrm{Aj}=\mathrm{Ct}=\mathrm{Ml}$ \\
\hline $\operatorname{Ro} \times \operatorname{Tr}$ & 9 & 93.8981 & 1.05 & 0.4245 & \\
\hline Residual 3 & 32 & 89.4583 & & & \\
\hline \multicolumn{6}{|c|}{ Enteromorpha sp. } \\
\hline Ro & 3 & 229.0278 & 20.21 & $<0.0001$ & $\mathrm{D}=\mathrm{P}>\mathrm{M}=\mathrm{S}$ \\
\hline $\operatorname{Tr}$ & 3 & 25.8056 & 2.28 & 0.0985 & \\
\hline $\operatorname{Ro} \times \operatorname{Tr}$ & 9 & 17.4167 & 1.54 & 0.1775 & \\
\hline Residual 3 & 32 & 11.3333 & & & \\
\hline \multicolumn{6}{|c|}{ Porphyra suborbiculata } \\
\hline Ro & 3 & 210.9444 & 9.92 & 0.0001 & $\mathrm{~S}=\mathrm{M}>\mathrm{P}=\mathrm{D}$ \\
\hline $\operatorname{Tr}$ & 3 & 106.8333 & 5.02 & 0.0058 & $\mathrm{~N}>\mathrm{Ml}=\mathrm{Aj}=\mathrm{Ct}$ \\
\hline $\operatorname{Ro} \times \operatorname{Tr}$ & 9 & 26.1111 & 1.23 & 0.3133 & \\
\hline Residual 3 & 32 & 21.2708 & & & \\
\hline \multicolumn{6}{|l|}{ Ulva sp. } \\
\hline Ro & 3 & 183.7222 & 8.17 & 0.0004 & $\mathrm{~S}>\mathrm{D}=\mathrm{M}=\mathrm{P}$ \\
\hline $\operatorname{Tr}$ & 3 & 72.9444 & 3.24 & 0.0348 & $\mathrm{~N}=\mathrm{Ct}=\mathrm{Ml}=\mathrm{Aj}$ \\
\hline $\operatorname{Ro} \times \operatorname{Tr}$ & 9 & 32.4074 & 1.44 & 0.2128 & \\
\hline Residual 3 & 32 & 22.5000 & & & \\
\hline \multicolumn{6}{|l|}{ Hурпеа sp. } \\
\hline Ro & 3 & 106.3889 & 16.91 & $<0.0001$ & $\mathrm{M}=\mathrm{D}>\mathrm{P}=\mathrm{S}$ \\
\hline $\operatorname{Tr}$ & 3 & 2.9444 & 0.47 & 0.7067 & \\
\hline $\operatorname{Ro} \times \operatorname{Tr}$ & 9 & 4.3704 & 0.69 & 0.7086 & \\
\hline Residual 3 & 32 & 6.2917 & & & \\
\hline
\end{tabular}




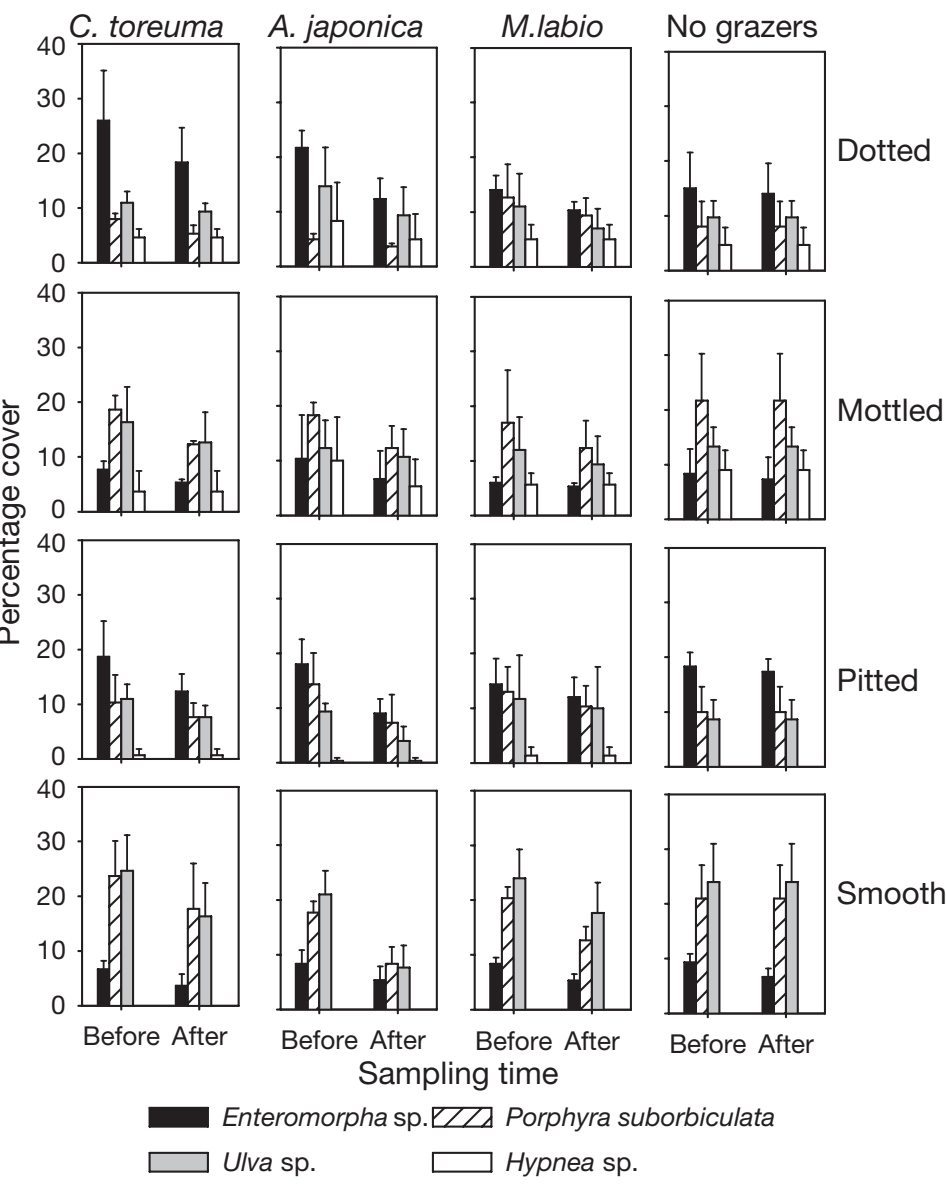

Fig. 4. Mean $(+\mathrm{SD}, \mathrm{n}=3)$ percentage cover of macroalgae on rock slabs prior to and following grazer introduction. Full grazer species names as in Fig. 1

by Acanthopleura japonica. It was not clear in the present study whether grazers ingested the algae, or dislodged them from the rock surface from which they were subsequently washed off (see Norton \& Fetter 1981). While it has been argued (Steneck \& Watling 1982) that the radula structure of grazers may limit species to feeding on certain algae, grazers may still indirectly remove some species from the rock surface while feeding on other species (see Mitchell \& Wass 1996).

Grazers appeared to be more efficient in removing species from some rock roughnesses than others, with Cellana toreuma reducing cover to the largest extent on smooth grades and Acanthopleura japonica on pitted grades. This could be due to variation in foraging behaviour on slabs of different roughness, or differences between grazers in the ability of their radula to remove species from different surfaces (Hawkins et al. 1989, Wahl \& Hoppe 2002). Whatever the cause, such variation may lead to different spatial patterns of biofilm distribution on the shore, depending on grazer abundance and local spatial variation in rock roughness. Grazers with differing radula structure (as described by Steneck \& Dethier 1994), will therefore have different efficiencies in removing algal species, as grazers with certain radula sizes may have limited access to food that is found in refuges (in our case pits on the rock surface) in a similar way that herbivores in streams have limited access to food in small cracks on rock surfaces (Dudley \& D'Antonio 1991). In the present study, for example, while the size of the radula teeth of grazers could mean that cusps of the radula would fit into pits on all roughness grades, the total width of the radula could mean that some grazers would have greater difficulty grazing on food sources within pits than on adjacent open surfaces, leading to spatial escapes from grazing for food species in pits. The morphology of food items, both in pits and on the open surface may also be a factor limiting the ability of grazers to remove them from the rock (Hawkins et al. 1989). It has been suggested, for example, that grazers remove more filamentous than unicellular biofilm species from certain substrates due to the morphological structure of the former, rather than through preferential feeding behaviour (Williams 1992). Variation in abundance of grazers with different radula structures on a shore may, therefore, have an effect on biofilm composition, depending on whether rock surface roughness varies within their foraging ranges. Such effects may be further reduced on softer rock surfaces, where grazers may be able to remove portions of the rock surface (Black et al. 1988, Norton et al. 1990) and access epilithic food-sources otherwise protected by such microscale topographical features.

Microscale spatial variation (variation within millimetres) in biofilm cover on rock slabs can also be seen on natural rocky shores and may be due to variation in refuges on rough surfaces and exacerbated by spatial variation in grazing by different species on the shore (see Hutchinson \& Williams 2003). The cyanobacteria and diatoms found on the slabs in the present study have previously been recorded on rocky shores in Hong Kong and are a food source for the grazers on these shores (Kaehler 1996, Nagarkar 1998). While grazers may have an effect on the abundance of biofilm species on the high shore (Mak \& Williams 1999) and during stages of primary succession in the mid shore (Williams et al. 2000), the long-term effects of such patchy grazing, as seen on local shores, is a subject of debate. Turnover rates of epilithic biofilm species have been shown to be extremely fast (MacLulich 1986), and after short periods of time species occur that 
are less susceptible to grazing (Hudon \& Bourget 1981, Lubchenco \& Gaines 1981). Initial colonisation of rocky shores is by bacteria, cyanobacteria, diatoms and macroalgal spores (MacLulich 1986), which are strongly affected by surface roughness (Norton \& Fetter 1981) and grazing by molluscs (Williams 1992). In later successional stages, however, assemblages are more developed, with thicker biofilms of diatoms and cyanobacteria (Blinn et al. 1980), encrusting algae, and invertebrates that may only be susceptible to roughness and grazing during the period when they first settle on the shore, after which they attain a size refuge (Kaehler \& Williams 1997).

The present study suggests that the interaction between grazing by different molluscan species and rock surface roughness contributes to small-scale patchiness within rocky intertidal communities (Hill \& Hawkins 1990) in Hong Kong. As such, grazers and their interaction with physical surface structures may be responsible for a larger amount of variation in distribution and abundance of species than is presently thought, and their accumulated impact may influence larger-scale community patterns on these shores.

Acknowledgements. We thank F. Simpson and the gentleman we only know as 'Mr. Granite' for providing rock in the early stages of this study. This work was conducted in partial fulfilment for a PhD by N.H. and supported by a part-time demonstratorship at The University of Hong Kong. Partial support was provided by a Science Faculty Seed Grant to G.A.W. and J.C.A. Thanks to the H.K.U. rocky shore ecology group and P. Moore at the MBA for critical comments on the text.

\section{LITERATURE CITED}

Black R, Lymbery A, Hill A (1988) Form and function: size of radular teeth and inorganic content of faeces in a guild of grazing molluscs at Rottnest Island, Western Australia. J Exp Mar Biol Ecol 121:22-35

Blinn DW, Fredericksen A, Korte V (1980) Colonization rates and community structure of diatoms on three different rock substrata in a lotic system. Br Phycol J 15:303-310

Caffey HM (1982) No effect of naturally occurring rock types on settlement or survival in the intertidal barnacle Tessoropora rosea (Krauss). J Exp Mar Biol Ecol 63:119-132

Crisp DJ, Barnes H (1954) The orientation and distribution of barnacles at settlement with particular reference to surface contour. J Anim Ecol 23:142-162

Dudley TL, D'Antonio CM (1991) The effects of substrate texture, grazing, and disturbance on macroalgal establishment in streams. Ecology 72:297-309

Dye AH (1993) Recolonization of intertidal macroalgae in relation to gap size and molluscan herbivory on a rocky shore on the east coast of southern Africa. Mar Ecol Prog Ser 95:263-271

Faimali M, Garaventa F, Terlizzi A, Chiantore M, CattenaoVietti R (2004) The interplay of substrate nature and biofilm formation in regulating Balanus amphitrite Darwin, 1854 larval settlement. J Exp Mar Biol Ecol 306:37-50

Franz CJ (1990) Feeding patterns of Fissurella species on Isla de Margarita, Venezuela: use of radulae and food passage rates. J Molluscan Stud 56:25-35

Harlin MM, Lindbergh JM (1977) Selection of substrata by seaweeds: optimal surface relief. Mar Biol 40:33-40

Hawkins SJ (1981) The influence of season and barnacles on the algal colonization of Patella vulgata exclusion areas. J Mar Biol Assoc UK 61:1-15

Hawkins SJ, Hartnoll RG (1982) The influence of barnacle cover on the numbers, growth and behaviour of Patella vulgata on a vertical pier. J Mar Biol Assoc UK 62:855-867

Hawkins SJ, Hartnoll RG (1983) Grazing of intertidal algae by marine invertebrates. Oceanogr Mar Biol Annu Rev 21: 195-282

Hawkins SJ, Watson DC, Hill AS, Harding SP, Kyriakides MA, Hutchinson S, Norton TA (1989) A comparison of feeding mechanisms in microphagous, herbivorous, intertidal prosobranchs in relation to resource partitioning. J Molluscan Stud 55:151-165

Hay ME, Fenical W (1988) Marine plant-herbivore interactions: the ecology of chemical defense. Annu Rev Ecol Syst 19:111-115

Hill AS, Hawkins SJ (1990) An investigation of methods for sampling microbial films on rocky shores. J Mar Biol Assoc UK 70:77-88

Hill AS, Hawkins SJ (1991) Seasonal and spatial variation of epilithic microalgal distribution and abundance and its ingestion by Patella vulgata on a moderately exposed rocky shore. J Mar Biol Assoc UK 71:403-423

Hoffmann AJ, Ugarte R (1985) The arrival of propagules of marine macroalgae in the intertidal zone. J Exp Mar Biol Ecol 92:83-95

Hudon C, Bourget E (1981) Initial colonisation of artificial substrates: community development and structure studied by scanning electron microscopy. Can J Fish Aquat Sci 38: 1371-1384

Hutchinson N, Williams GA (2001) Spatio-temporal variation in recruitment on a seasonal, tropical rocky shore: the importance of local versus non-local processes. Mar Ecol Prog Ser 215:57-68

Hutchinson N, Williams GA (2003) An assessment of variation in molluscan grazing pressure on Hong Kong rocky shores. Mar Biol 142:495-507

Kaehler S (1996) Causes and consequences of the spatial and temporal distribution of encrusting algae on tropical rocky shores. PhD thesis, University of Hong Kong

Kaehler S, Williams GA (1997) Do factors influencing recruitment ultimately determine the distribution and abundance of encrusting algae on seasonal tropical shores? Mar Ecol Prog Ser 156:87-96

Kerr A, Beveridge CM, Cowling MJ, Hodgkiess T, Parr ACS, Smith MJ (1999) Some physical factors affecting the accumulation of biofouling. J Mar Biol Assoc UK 79:357-359

Khan KR (1969) Ecology of some littoral blue-green algae of Oahu. Rev Algol NS 9:217-230

Kostylev V (1996) Spatial heterogeneity and habitat complexity affecting marine littoral fauna. $\mathrm{PhD}$ thesis, Göteborg University

Linskens HF (1966) Adhäsion von Fortpflanzungzellen benthonischer Algen. Planta 68:99-110

Lubchenco J, Gaines SD (1981) A unified approach to marine plant-herbivore interactions. I. Populations and communities. Annu Rev Ecol Syst 12:405-437

MacLulich JH (1986) Colonization of bare rock surfaces by microflora in a rocky intertidal habitat. Mar Ecol Prog Ser 32:91-96

Mak YM, Williams GA (1999) Littorinids control high intertidal biofilm abundance on tropical, Hong Kong rocky shores. J Exp Mar Biol Ecol 233:81-94 
Mitchell SF, Wass RT (1996) Quantifying herbivory: grazing consumption and interaction strength. Oikos 76:573-576

Nagarkar S (1998) New records of marine cyanobacteria from rocky shores of Hong Kong. Bot Mar 41:527-542

Nagarkar S, Williams GA (1997) Comparative techniques to quantify cyanobacteria dominated epilithic biofilms on tropical rocky shores. Mar Ecol Prog Ser 154:281-291

Nagarkar S, Williams GA (1999) Spatial and temporal variation of cyanobacteria-dominated epilithic communities on a tropical shore in Hong Kong. Phycologia 38: 385-393

Nicotri ME (1980) Factors involved in herbivore food preference. J Exp Mar Biol Ecol 42:13-26

Norton TA, Fetter R (1981) The settlement of Sargassum muticum propagules in stationary and flowing water. J Mar Biol Assoc UK 61:929-940

Norton TA, Hawkins SJ, Manley NL, Williams GA, Watson DS (1990) Scraping a living: a review of littorinid grazing. Hydrobiologia 193:117-138

Percival SL, Knapp JS, Wales DS, Edyvean RGJ (1999) The effect of turbulent flow and surface roughness on biofilm formation in drinking water. J Ind Microbiol Biotechnol 22:152-159

Raffaelli D (1985) Functional feeding groups of some intertidal mollsuscs defined by gut contents analysis. J Molluscan Stud 51:233-239

Railkin AI (2003) Marine biofouling: colonization processes and defenses. CRC Press, Boca Raton, FL

Raimondi PT (1988) Rock type affects settlement, recruitment, and zonation of the barnacle Chthamalus anisopoma Pilsbury. J Exp Mar Biol Ecol 123:253-267

Round FE, Crawford RM, Mann DG (1990) The diatoms. Cambridge University Press, Cambridge

Sanson GD, Stolk R, Downes BJ (1995) A new method for characterizing surface roughness and available space in biological systems. Funct Ecol 9:127-135

Santos R, Callow ME, Bott TR (1991) The structure of Pseudomonas fluorescens biofilms in contact with flowing systems. Biofouling 4:319-336

Shreve GS, Olsen RH, Vogel TM (1991) Development of pure culture biofilms of $P$. putida on solid supports. Biotechnol Bioeng 37:512-518

Sousa WP (1979) Experimental investigations of disturbance and ecological succession in a rocky intertidal algal community. Ecol Monogr 49:227-254

Sousa WP (1984) Intertidal mosaics: patch size, propagule availability, and spatially variable patterns of succession. Ecology 65:1918-1935

Editorial responsibility: James Ammerman,

New Brunswick, New Jersey, USA
Steneck RS, Dethier MN (1994) A functional group approach to the structure of algal-dominated communities. Oikos 69:476-498

Steneck RS, Watling L (1982) Feeding capabilities and limitation of herbivorous molluscs: a functional group approach. Mar Biol 68:299-319

Stephenson W (1961) Experimental studies on the ecology of intertidal environments at Heron Island. II. The effect of substratum. Aust J Mar Freshw Res 12:132-188

Thompson RC, Tobin ML, Hawkins SJ, Norton TA (1999) Problems in the extraction and spectrophotometric determination of chlorophyll from epilithic microbial biofilms: towards a standard method. J Mar Biol Assoc UK 79: $551-558$

Underwood AJ, Jernakoff P (1981) Effects of interactions between algae and grazing gastropods on the structure of a low-shore intertidal algal community. Oecologia 48: 221-223

Underwood AJ, Denley EJ, Moran MJ (1983) Experimental analyses of the structure and dynamics of mid-shore rocky intertidal communities in New South Wales. Oecologia 56: 202-219

Wahl M (1989) Marine epibiosis. I. Fouling and antifouling: some basic aspects. Mar Ecol Prog Ser 58:175-189

Wahl M, Hoppe K (2002) Interactions between substratum rugosity, colonization density and periwinkle grazing efficiency. Mar Ecol Prog Ser 225:239-249

Walters LJ, Wethey DS (1996) Settlement and early postsettlement survival of sessile invertebrates on topographically complex surfaces: the importance of refuge dimensions and adult morphology. Mar Ecol Prog Ser 137:161-171

Watson DC, Norton TA (1987) The habitat and feeding preferences of Littorina obtusata (L.) and L. mariae Sacchi et Rastelli. J Exp Mar Biol Ecol 112:61-72

Williams GA (1992) The effects of grazing by Littorina mariae on diatom assemblages on natural and artificial surfaces. In: Grahame J, Mill PG, Reid DG (eds) Proceedings of the Third International Symposium on Littorinid Biology. The Malacological Society, London, p 211-219

Williams GA (1993) The relationship between herbivorous molluscs and algae on moderately exposed Hong Kong shores. In: Morton B (ed) The First International Conference on the Marine Biology of Hong Kong and the South China Sea. Hong Kong University Press, Hong Kong, p 459-470

Williams GA, Davies MS, Nagarkar S (2000) Primary succession on a seasonal tropical rocky shore: the relative roles of spatial heterogeneity and herbivory. Mar Ecol Prog Ser 203:81-94

Submitted: July 1, 2004; Accepted: November 1, 2005

Proofs received from author(s): February 13, 2006 